\title{
Aflatoxins, Carcinogens in Food, as Etiological Factors in Human Malignant Neoplasias of the Lung
}

Magda Carvajal-Moreno*, Erika Alejandra García-Hernández, María Del Carmen González-Villaseñor, Areli E González-Mendoza and Valentín A Rojas-Marín Department of Botany, Institute of Biology, National Autonomous University of Mexico, Avenida Universidad, University City, Delegación Coyoacán, CdMx, Mexico

*Corresponding author: Magda Carvajal-Moreno, Department of Botany, Institute of Biology, National Autonomous University of Mexico, Avenida Universidad 3000, University City, Delegación Coyoacán 04510 CdMx, Mexico, Tel: +5255-2523 8197; E-mail: magdac@ib.unam.mx

Rec date: August 13, 2018; Acc date: October 09, 2018; Pub date: October 11, 2018

Copyright: (c) 2018 Carvajal-Moreno M, et al. This is an open-access article distributed under the terms of the creative common's attribution license, which permits unrestricted use, distribution, and reproduction in any medium, provided the original author and source are credited.

\begin{abstract}
Lung cancer is a malignant neoplasm of the lung or bronchial cells and is one of the primary causes of mortality in men and is the third leading cause of death in women worldwide. Active and passive tobacco smoking are considered the main risk factors for the development of lung cancer, but aflatoxins have also been considered important etiological factors. Aflatoxins, which are fungal secondary metabolites produced primarily by Aspergillus spp., are chemically bis or tetra-hydrodifuran coumarins that contaminate foods (cereals, oilseeds, spices, dry fruits and dairy products). Aflatoxins are better recognized as hepatocarcinogens, but they can cause lung cancer via the formation of links to DNA and by the formation of $\mathrm{AFB}_{1}$-DNA adducts, which can remain in the DNA for years and cause mutations and eventually cancers. The ingestion of aflatoxin-contaminated foods is the most common way in which individuals are exposed to these carcinogens, but other routes of exposure include nasal aerosol inhalation of $A \mathrm{AB}_{1}$, which damages the lung. Alveolar macrophages possess specific oxidase activity for the epoxidation of $\mathrm{AFB}_{1}$. In the biotransformation of the lung by $\mathrm{AFB}_{1}, \mathrm{AFB}_{1}$ requires a catalyzed metabolic activation of cytochrome $\mathrm{P} 450$ (CYP), the levels of which are low in the lung, to exert its carcinogenic activity. $\mathrm{AFB}_{1}$ activation in the lung is achieved by prostaglandin H-synthetize, lipoxygenases, and CYP2A13 enzymes, the last of which catalyzes metabolic activation. CYP2A13 also plays a critical role in human lung carcinogenesis associated with inhalation exposure to $A F B_{1}$ and is highly efficient in the activation of $A F B_{1}$ in situ. Aflatoxins $\left(A F B_{1}\right.$ and $\left.A F G_{1}\right)$ cause point mutations in $\mathrm{K}$-Ras and $\mathrm{H}$-Ras as well as in the $p 53$ tumor suppressor gene, which can cause lung cancer. This article summarizes the known etiology of lung cancer with respect to the human food carcinogens $A F B_{1}$ and $A F G_{1}$, the molecular mechanisms of aflatoxins, and the known point mutations in the $K$-Ras, $H$-ras and $p 53$ genes. This article also discusses a possible biocontrol (creosote bush or Larrea tridentata), the use of which is limited by its toxicity.
\end{abstract}

Keywords: Aflatoxins; Lung cancer; Carcinogens; Mycotoxins; Point mutations; $p 53$ genes; Bronchial cells

\section{Introduction}

Currently, cancer is the most important group of diseases that affect human society worldwide. The incidence of cancer has increased in the last several years, primarily in underdeveloped countries, due to population growth and to different risk factors such as tobacco smoking, fatness, physical inactivity, genetics and mycotoxins, among others. In 2012, 14.1 million of new cases of cancer were reported, and 8.2 million cancer-related deaths were reported worldwide $[1,2]$.

Lung Cancer (LC) is one of the most common causes of cancer mortality in men and is the third cause of death in women worldwide. It has been suggested that there will be 1.8 new cases worldwide, with the highest incidence seen in underdeveloped countries [1,2]. Aflatoxins can cause different types of cancers in different organs such as the lungs [3], liver [4], colon [5], rectum [5], pancreas [6], kidney [7], and cervix [8]. In the lung, malignant neoplasia may develop from either the lung parenchyma or bronchial cells. Recently, the frequency of lung cancer has increased substantially, and it is now considered one of the most frequently detected malignant tumors. The World Health Organization (2015) classified the origins of LC as epithelial, mesenchymal, lymph histiocytic, ectopic or metastatic [9].
The symptomatology varies depending on the development of the disease. Symptoms include cough, dyspnea, recurrent pneumonia, and paraneoplastic syndrome, among others. Since the symptoms are diverse and may overlap with those of other diseases, the prognosis depends on the early or late detection of the disease.

Active and passive tobacco smoking are considered the main risk factors for the development of $\operatorname{LC}[10,11]$, but in recent years, aflatoxins have also been considered important etiological factors [12]. Other risk factors include obesity, physical inactivity, improper nutrition, genetic load and exposure to different substances such as arsenic, asbestos and radon.

\section{Literature Review}

\section{Aflatoxins}

Aflatoxins (AF) are secondary metabolites produced mainly by the fungi Aspergillus flavus, A. parasiticus and A. nomius [13]. More than 20 known AFs have been identified, but the basic four are aflatoxin B1 $\left(\mathrm{AFB}_{1}\right)$, aflatoxin $\mathrm{B} 2\left(\mathrm{AFB}_{2}\right)$, aflatoxin $\mathrm{G} 1\left(\mathrm{AFG}_{1}\right)$ and aflatoxin $\mathrm{G} 2$ $\left(\mathrm{AFG}_{2}\right)$ [14]. To detoxify the body from $\mathrm{AFB}_{1}$, which is the most toxic $\mathrm{AF}$, the liver adds the chemical group $\mathrm{OH}$ - to these compounds to form hydroxylated metabolites. These metabolites are water-soluble and can be present in urine, lymph, and milk, among other body fluids. The primary hydroxylated metabolites are aflatoxin M1 (AFM $)_{1}$, aflatoxin 
Citation: Carvajal-Moreno M, García-Hernández EA, González-Villaseñor MDC, González-Mendoza AE, Rojas-Marín VA (2018) Aflatoxins, Carcinogens in Food, as Etiological Factors in Human Malignant Neoplasias of the Lung. J Cancer Sci Ther 10: 294-301. doi:

M2 $\left(\mathrm{AFM}_{2}\right)$, aflatoxin P1 $\left(\mathrm{AFP}_{1}\right)$ and aflatoxicol (AFL); this last compound is interconvertible with $\mathrm{AFB}_{1}$ and can be stored as $\mathrm{AFB}_{1}$ [15].

The chemical structure of AFs is a dihydrodifuran or tetrahydrodifuran ring joined to a coumarin by a ring of 5 to 6 carbon atoms (Figure 1). AFs are solid crystals that are odorless, flavorless and colorless and that are slightly soluble in water but very soluble in organic solvents such as methanol, acetonitrile, hexane, and chloroform [16].<smiles>COc1cc2c(c3oc(=O)c4c(c13)CCC4=O)C1C=COC1O2</smiles>

Aflatoxin $B_{1}$<smiles>COc1cc2c(c3oc(=O)c4c(c13)CCOC4=O)C1CCOC1O2</smiles>

Aflatoxin $\mathbf{G}_{2}$<smiles>COc1cc2c(c3oc(=O)c4c(c13)CCC4=O)C1CCOC1O2</smiles>

Aflatoxin $B_{2}$<smiles>COc1cc2c(c3oc(=O)c4c(c13)CCC4=O)C1(O)C=COC1O2</smiles>

Aflatoxin $\mathrm{M}_{1}$<smiles>COc1cc2c(c3oc(=O)c4c(c13)CCOC4=O)C1C=COC1O2</smiles>

Aflatoxin $\mathbf{G}_{1}$<smiles>COc1cc2c(c3oc(=O)c4c(c13)CCC4=O)C1(O)CCOC1O2</smiles>

Aflatoxin $\mathrm{M}_{2}$<smiles>O=C1CCc2c1c(=O)oc1c3c(cc(O)c21)OC1OC=CC31</smiles>

Aflatoxin $P_{1}$<smiles>COc1cc2c(c3oc(=O)c4c(c13)CCC4=O)C1C=COC1O2</smiles>

Aflatoxicol

Figure 1: Chemical structure of AFs is a dihydrodifuran or tetrahydrodifuran ring joined to a coumarin by a ring of 5 to 6 carbon atoms.

Since the discovery of AFs as etiological factors of Turkey $\mathrm{X}$ disease, which was responsible for the deaths of 100,000 young turkeys in Great Britain in 1960, AFs have been the most studied mycotoxins $[17,18]$. The first outbreak of aflatoxins, which caused the deaths of 100 people, was reported in India [19].
The fungi that produce aflatoxins grow in a large variety of foods such as cereals (maize [20], rice [21], barley, oat and sorghum [17], oilseeds (peanuts [22], pistachios [23], almonds [24], nuts [25], and cotton seeds), and spices such as hot peppers [26] and black pepper [27]. Milk and dairy products can also be contaminated with $\mathrm{AFM}_{1}$, which is the most common hydroxylated metabolite of $\mathrm{AFB}_{1}[28,29]$. 
$\mathrm{AFM}_{1}$ can be detected in milk 12 to 24 hours after the cow has consumed feed contaminated with $\mathrm{AFB}_{1}$. $\mathrm{AFM}_{1}$ can also be detected in dairy products such as cheese and in a higher concentration than in milk [30].

Aflatoxins affect the absorption and metabolism of carbohydrates, proteins, lipids, vitamins and minerals, and their toxicity affects the electron transport of the respiratory chain and the cell membranes. Changes at the cellular level caused by aflatoxins in animal and plant cells are as follows: Nucleolus appears as a ring with different layers, presence of lipid bodies, mitochondria with elongated cisterns, endoplasmic reticulum without granulations, presence of elongated and irregular nuclei and the presence of highly granular chromatin [31]. Aflatoxins can also function as antimetabolites that link to DNA, where they interfere with ARN and protein synthesis [32].

\section{Aflatoxins and lung cancer}

Aflatoxin contamination can produce acute symptoms such as hemorrhage, vomiting, abortion, and death if the ingested amounts are high. Chronic symptoms such as hepatitis, cirrhosis, immunodepression, fetal malformations, and cancer may develop if the ingested amounts are low and if exposure occurs over long periods of time. These symptoms are observed in animals such as pets as well as in humans, with the liver as the target organ [28] for aflatoxins. $\mathrm{AFB}_{1}$ is classified by the International Agency for Research on Cancer (IARC, 2002) [33] as a Group I carcinogen, as it has been demonstrated to be carcinogenic in humans; in contrast, $\mathrm{AFM}_{1}$ is classified as a Group 2B substance, or one that is possibly carcinogenic in humans [34]. Acute toxicity is more frequent in underdeveloped countries, especially those in Africa, but the chronic effects of aflatoxins cause cancer in many different countries worldwide $[28,35]$.

One of the main reasons why aflatoxins are considered potent carcinogens is their ability to form mutagenic adducts in DNA. These adducts can be formed up in cells, and when they accumulate, DNA repair is difficult, and mutations may be generated [36]. $\mathrm{AFB}_{1}$ itself is not mutagenic, as it requires bio activation by cytochrome $\mathrm{P} 450$ to be transformed in exo-epoxide- $8,9-\mathrm{AFB}_{1}$, which is a carcinogen itself. The exo-epoxide-8,9-AFB ${ }_{1}$ links to $\mathrm{N} 7$ in the guanine nucleotide, which forms a DNA adduct $[37,38]$.

\section{Routes of exposure}

Regarding the routes of exposure necessary for DNA adduct formation in rats, Zarba (1992) [39] studied the liver following either an intra-tracheal injection or nose-only aerosol inhalation exposure to $\mathrm{AFB}_{1}$. Aerosol inhalation is an effective route of exposure for $\mathrm{AFB}_{1}$ in rats and hamsters and results in genotoxic damage to the liver. The binding of intra-tracheal-administered $[3 \mathrm{H}] \mathrm{AFB}_{1}$ to rat liver DNA is only marginally higher than that observed in hamster liver, which is in contrast to the large difference observed in animals that received $\mathrm{AFB}_{1}$ intraperitoneally. A positive association was observed between the development of human lung cancer and inhalation exposure to $\mathrm{AFB}_{1}$.

The lungs are the second most important organ after the liver with respect to their ability to retain a considerable amount of tritiated [3H] $\mathrm{AFB}_{1}(66 \%) . \mathrm{AFB}_{1}$ that binds to DNA in the liver approached a peak 1 $\mathrm{hr}$ after the intra-tracheal administration of the toxin to rats and hamsters [40]. The persistence of the binding of $\mathrm{AFB}_{1}$ to DNA in the lung and the extent of alveolar macrophages possess specific mixed function oxidase activity for the epoxidation of $\mathrm{AFB}_{1}[40]$.
On the contrary, the route of administration of the carcinogen did not affect DNA binding over time in sprout-fed animals [41,42]. Rather, it was found that the nasal mucosa of some mammalian species is susceptible to the toxic effects of $\mathrm{AFB}_{1}$, and thus, some investigators have studied the nasal enzymes involved in the metabolic activation of $\mathrm{AFB}_{1}$ and the metabolites produced in nasal microsomes (NMa). Members of the $P 4502 A$ gene subfamily play an important role in the metabolic activation of $\mathrm{AFB}_{1}$ in rabbit and rat nasal mucosa, which suggests a molecular basis for the assessment of the health risk associated with inhalation exposure of humans to this procarcinogen. The rates of $\mathrm{AFB}_{1}-\mathrm{N} 7$-guanine DNA adduct formation in rabbit and rat NMa are over 3- and 10-fold higher, respectively, than in liver microsomes from the same species [42]. In contrast, the rates of formation of $\mathrm{AFM}_{1}$ (9a-hydroxy-AFB 1 ) and $\mathrm{AFQ}_{1}$ (3-hydroxy-AFB ${ }_{1}$ ) products, which are known to be less toxic, are lower in nasal than in liver microsomes. Nasal microsomes produce high levels of six unidentified polar metabolites that are not formed by microsomes from the liver or by those from several other tissues. Furthermore, the formation of $\mathrm{AFB}_{1}-\mathrm{DNA}$ adducts by nasal microsomes is decreased by nicotine, a known inhibitor of P450 NMa [42].

\section{Biotransformation of $\mathrm{AFB}_{1}$ in the lungs}

$\mathrm{AFB}_{1}$ requires the catalyzed metabolic activation of cytochrome P450 (CYP) to exert its carcinogenic activity. The major enzymes for $\mathrm{AFB}_{1}$ activation in the human liver are $C Y P 1 A 2$ and $C Y P 3 A 4$ [43]. However, in the case of the lungs, $C Y P 2 A 13$ is an enzyme that is predominantly expressed in the human respiratory tract. $C Y P 2 A 13$ is highly efficient and can readily activate $A_{F B}$ to the epoxides $A_{F B}$ and $\mathrm{AFM}_{-8,9}$ in situ [44]. The catalyzed metabolic activation of CYP2A13 in situ may play a critical role in human lung carcinogenesis associated with inhalation exposure to $\mathrm{AFB}_{1}$ [45]. In human cells, cytochrome $\mathrm{P} 450$ is expressed in the respiratory tract.

Residues Ala 117 and His 372 in cytochrome P450 2A13 are important for the epoxidation of $\mathrm{AFB}_{1}$ and its cytotoxicity [45]. $\mathrm{AFB}_{1}$ activation by cytochrome $\mathrm{P} 450$ occurs at low levels in the lungs, and thus, $\mathrm{AFB}_{1}$ is activated by other enzymes such as prostaglandin $\mathrm{H}$ synthetase (PHS) [46,47] and lipoxygenases (LOX) [48], which are expressed at high levels in the lung. The expression of genes that code for xenobiotic metabolism enzymes in human bronchial and alveolar macrophages has been reported [49].

\section{Aflatoxins in lung cancer}

Lung cancer was first associated with AF exposure (mainly with $\mathrm{AFB}_{1}$ ) in the 1980s after it was found during the biopsy of malignant lung tissues of two patients with lung Aspergillosis [3]. Now, a positive association has been demonstrated between human lung cancer and the exposure to or inhalation of $\mathrm{AFB}_{1}$ [45].

\section{Mutations in the K-Ras and $\mathrm{H}$-Ras oncogenes point mutations and mutations in the tumor suppressor gene p53}

When rats, mice and fish ingest an AF-contaminated diet, some proto-oncogenes of the "ras" family are activated [50,51]. High incidences of activated $\mathrm{K}$-ras and $\mathrm{N}$-ras have been observed in liver carcinomas and adenomas induced by $\mathrm{AFB}_{1}$ [52]. Activation of the ras proto-oncogene has also been found in $\mathrm{AFB}_{1}$-induced tumors in mice, rats, and fish. The relationship between aflatoxin exposure and the development of human hepatocellular carcinoma (HHC) was demonstrated by studies on the Tp53 tumor suppressor gene. A high 
Citation: Carvajal-Moreno M, García-Hernández EA, González-Villaseñor MDC, González-Mendoza AE, Rojas-Marín VA (2018) Aflatoxins, Carcinogens in Food, as Etiological Factors in Human Malignant Neoplasias of the Lung. J Cancer Sci Ther 10: 294-301. doi: 10.4172/1948-5956.1000559

frequency of $\mathrm{p} 53$ mutations ( $\mathrm{G} \rightarrow \mathrm{T}$ transversion at codon 249) was found to occur in HHC tissues collected from populations exposed to high levels of dietary aflatoxin in China and Southern Africa [52].

The expression of both the Ras gene and Ras protein is commonly associated with alterations in tumors that increase invasiveness and metastasis and that decrease apoptosis. Molecules of this group function as regulatory-interrupters of signaling pathways such as the integrity of the cytoskeleton, proliferation, differentiation, attachment and migration. Activation of the proto-oncogene Ras, which occurs by point mutations in hot spots of codons 12,13 and 61 , is an early event in carcinogenesis and has been studied in lung tumorigenesis in mice. The pattern of point mutations that activate the $K$-ras oncogene reveals the nature of aflatoxin carcinogens [50]. The proto-oncogenes Kras-2 in the lung and Hras-1 in the liver, which are both expressed in mice, are the most common induced or spontaneous mutations reported. The proto-oncogene Kras-2 and the tumor suppressor gene Tp53 exhibit the major genetic alterations reported in the human lung. The incidence of Kras-2 mutations was similar to that of asbestos-induced human lung tumors, while the incidence of Tp53 mutations differed significantly [51]. $\mathrm{AFB}_{1}$, hepatitis $\mathrm{B}$ and $\mathrm{C}$ viruses, and vinyl chloride induced Tp53 mutations in human liver tumors but with different mutation spectra. Mutation spectra serve as "fingerprints" of exposure and is based on chemical structure [51].

Oncogenes such as $\mathrm{N}$-ras, $c$-myc and $c$-fos are over-expressed, but mutations in these genes are rare [53]. A specific mutation in codon 249 of the $T p 53$ gene is present in individuals who live in regions where HCC and exposure to AFs are prevalent [54] and is considered to be a "hotspot" for mutations induced by $\mathrm{AFB}_{1}$ [38]. The transversion $\mathrm{G} \rightarrow \mathrm{T}$ or the transition $\mathrm{G} \rightarrow \mathrm{A}$ occurs in the third base of codon 249 (AGG AGT) of the Tp53 gene and results in a change of amino acids from arginine to serine. This mutation is described as a dactylic fingerprint that shows $\mathrm{AFB}_{1}$ exposition [55]. Another fingerprint that is indicative of $\mathrm{AFB}_{1}$ presence is located in the first or second base of codon 12 of the $H$-ras gene [56-59].

An early event in the carcinogenesis of the lung is the transversion mutation G-T in the proto-oncogene $K$-ras. This mutation is caused by the association of $\mathrm{AFB}_{1}$ (8-hydroxi-2'-desoxiguanosin) with DNA. In one study, tumors grew larger after exposure to polyethylene glycolconjugated catalase, which was not protective against $\mathrm{AFB}_{1}$-induced carcinogenicity in the mouse lung even though it prevented DNA oxidation [60]. The presence of $\mathrm{AFB}_{1}$ in human bronchial epithelial cells has been observed along with a concomitant decrease in expression of the tumor suppression gene $p 53$ [61].

Although $\mathrm{AFB}_{1}$ is best known as a hepatocarcinogen, the respiratory system can also be a target. In lung cells isolated from rabbits and mice, $\mathrm{AFB}_{1}$ is biologically activated by cytochrome $\mathrm{P} 450$ and $K$-ras mutations occur primarily in non-ciliated bronchiolar epithelial (Clara) cells. In agreement with the $\mathrm{DNA}$ adduct, $\mathrm{AFB}_{1}$-induced $\mathrm{AC} 3 \mathrm{~F} 1$ mouse lung tumors contain point mutations in guanine residues of $K$-ras [12].

$\mathrm{AFB}_{1}$-induced mouse lung tumors overexpress p53 protein and demonstrate $p 53$ point mutations, which suggests that $\mathrm{AFB}_{1}$ induces a carcinogen-specific response. In contrast, the human lung bio-activates $\mathrm{AFB}_{1}$ primarily by prostaglandin $\mathrm{H}$ synthase and/or lipoxygenasecatalyzed co-oxidation, with activity concentrated in macrophages. Although glutathione S-transferase $\mathrm{M}_{1}-1\left(\mathrm{GSTM}_{1}\right)$ has high specific activity for $\mathrm{AFB}_{1}$ epoxide conjugation, lung tissues from $\mathrm{GSTM}_{1}$-null individuals show diminished rates of conjugation compared with tissues from $\mathrm{GSTM}_{1}$-positive individuals. $\mathrm{AFB}_{1}$-induced tumorigenesis in mice demonstrates unique properties, and the processes of bio activation show significant interspecies differences [12].

Of the 26 mutations found in micro-dissected regions from adenomas and carcinomas, 9 were G:C3 A:T transitions, 11 were A:T3G:C transitions, and 5 were transversions (2 G:C3T:A, 2 T:A3A:T, and 1 A:T3C:G), whereas 1 deletion mutation was identified. The concordance between immunostaining and the molecular detection of p53 alterations was $72 \%$ when laser capture microdissection was used versus $17 \%$ when whole tumor analysis was used. The high mutation frequency and heterogeneous staining pattern suggest that p53 mutations occur relatively late in $\mathrm{AFB}_{1}$-induced mouse lung tumorigenesis and emphasize the value of the analysis of different staining regions of paraffin- embedded mouse lung tumors [62].

In humans, the p53 or TP53 tumor suppressor gene, which is sometimes referred to as the "guardian of the genome", is located on the short arm of chromosome 17 (17p13) and codes for a nuclear transcription factor of $53 \mathrm{k} \mathrm{Da}$ [63]. It controls DNA damage, stops the cell cycle when mutations occur and plays an important role in apoptosis and senescence when the damage cannot be repaired. The p53 protein activates DNA repair enzymes so that they can correct the detected damage, and it also induces certain proteins such as GADD45 (=growth arrest and DNA damage) that cooperate in the DNA repair process. The $p 53$ protein activates the transcription of the miR34 microRNA family, which comprises small RNA molecules that prevent the translation of specific mRNAs to stop the cell cycle and apoptosis [64].

The cellular concentration of $p 53$ should be well regulated because although it can suppress tumors, a high level of $p 53$ can accelerate aging due to excessive apoptosis. A defective p53 protein could allow abnormal cells to proliferate, which may lead to cancer, as $50 \%$ of all human tumors have $p 53 \mathrm{~V}$ mutations and $80 \%$ of $p 53$ point mutations in human cancers are located in the DNA binding area of the protein. $p 53$ belongs to the same family of transcription factors as $p 63$ and $p 73$. The $p 53$ protein is ubiquitously expressed in all tissues, while $p 63$ and $p 73$ are tissue-specific. All members of this transcription factor family have isoforms that function as activators, while others function as dominant negatives [65]. The $p 53$ protein is a phosphoprotein formed by 393 amino acids and 3 domains:

1) One that activates transcription factors,

2) Another that recognizes the central domain of a DNA-specific sequence,

\section{3) A final-carboxyl domain (C-).}

The primary negative regulator of the tumor suppressor $p 53$ is the protein $M d m 2$ (=murine double minute 2), which can degrade p53. $M d m 2$ acts as an E3 ubiquitin ligase [65], which marks $p 53$ for degradation by a proteasome [66]. $M d m 2$ expression is also regulated by $p 53$, and thus, $p 53$ can be maintained at low levels once the cellular damage has been repaired [67].

The ability of $p 53$ to induce apoptosis in the presence of DNA damage has important therapeutic implications. The two main treatment modalities for cancer are irradiation and chemotherapy; these both cause damage to DNA, which activates apoptosis in tumor cells. The malignant tumors that retain $p 53$ will be cured by these treatments, but the tumors that present $p 53$-mutated alleles will be resistant because they will exhibit complications in the activation of apoptosis. Therefore, therapeutic modalities that increase p53 activity 
Citation: Carvajal-Moreno M, García-Hernández EA, González-Villaseñor MDC, González-Mendoza AE, Rojas-Marín VA (2018) Aflatoxins, Carcinogens in Food, as Etiological Factors in Human Malignant Neoplasias of the Lung. J Cancer Sci Ther 10: 294-301. doi: 10.4172/1948-5956.1000559

in malignant tumors that retain $p 53$ and those that selectively destroy tumor cells that lack $p 53$ are needed [64].

Approximately $40 \%$ of lung cancers present G>T mutations in codons 157, 158, 245, 248, 249 and 273 in the TP53 gene. Other types of cancers in which the $p 53$ gene is mutated are Li-Fraumeni syndrome, lymphatic leukemia and Hodgkin disease, cancers of the skin, breast, head, neck, esophagus, liver, stomach, colon, bladder, cervix, ovary, and prostate as well as glioblastoma and pancreatic adenocarcinoma [68].

The p53 tumor suppressor gene is implicated in the regulation of nucleotide excision repair (NER). $\mathrm{AFB}_{1}$ causes different mutations in cells, while $p 53$ regulates the repair of those mutations [69].

Aflatoxin $G_{1}\left(A_{F G}\right)$ is implicated in lung cancer, as its oral administration induces chronic alveolar inflammation, which is associated with lung tumorigenesis in mice, 3 to 6 months after treatment. The proliferation and angiogenesis of AT-II cells were induced in inflammatory tissues. Oxidative stress and cyclooxygenase 2 (COX-2) were increased in the alveolar epithelium of $\mathrm{AFG}_{1}$-treated mice. Oral gavage of AFG1 induced lung epithelial hyperplasia and adenocarcinoma in Balb/c mice 12 months after treatment [70].

The up-regulation of nuclear factor- $\mathrm{kB}(\mathrm{NF}-\mathrm{\kappa B})$, a key transcription factor that is thought to play a major role in carcinogenesis, regulates many important signaling pathways involved in tumor promotion. In addition, the expression of signal transducer and activator of transcription 3 (p-STAT3), and COX-2 was also induced in lung adenocarcinoma, which establishes a link between AFG1-induced chronic inflammation and lung tumorigenesis. Oral administration of AFG1, which could induce chronic lung inflammation, may provide a pro-tumor microenvironment that contributes to lung tumorigenesis [10].

Epidemiological studies have revealed an association between $\mathrm{AFB}_{1}$ exposure and lung cancer in humans. The bio activation and detoxification of $\mathrm{AFB}_{1}$ was observed in human lung tissue obtained from patients undergoing clinically indicated lobectomy. $[3 \mathrm{H}] \mathrm{AFB}_{1}$ was bio activated to a DNA binding metabolite by human whole lung cytosols and $\mathrm{AFB}_{1}$ in a concentration-dependent manner. The inhalation of $A B_{1}$ was supposed to cause primary lung cancer, and different tobacco sources:

a) Virginia of Jujuy,

b) Brasilero and

c) Black of Salta, presented $\mathrm{AFB}_{1}$-positive determinations.

The bronchial tissues obtained by lung biopsies presented positive $\mathrm{AFB}_{1}$ in lung epidermoid cancer. Additionally, 12 patients with chronic bronchitis who smoke presented an $\mathrm{AFB}_{1}$ level less than that in the epidermoid lung cancer group [71].

\section{Natural herbs as biocontrols for lung cancer caused by $\mathrm{AFB}_{1}$}

The use of plants for medicinal purposes was first recorded in Chinese, Egyptian, and Assyrian texts on herbal therapies. In 1985, the World Health Organization estimated in 1985 that $65 \%$ to $80 \%$ of the world's population rely on herbs for their medical needs [72], which is not surprising given that herbs serve as the basis for many drugs.

Larrea tridentata (creosote bush), which is known as greasewood in the United States (Arizona, California, Nevada, Texas and New Mexico) and as "gobernadora" or "hediondilla" in Mexican desert areas (San Luis Potosi, Coahuila, Chihuahua, Durango, Sonora, Zacatecas, Baja California), also grows in the arid zones of Argentina and Bolivia [73,74].

Aqueous extracts of creosote bush (chaparral tea) are used to treat a wide variety of disorders including chicken pox, skin sores, diabetes, kidney and gallbladder stones, cancer, venereal disease, tuberculosis, colds, and rheumatism $[74,75]$.

Creosote bush has shiny leaves with a thick resinous coating, a strong odor and a sour flavor. The resin-coated leaves yield many flavonoid aglycones, essential oils, halogenic alkaloids as well as several lignans such as the antioxidant nordi-hydroguaiaretic acid (NDGA) [76]. NDGA and other phenols of the leaf surface function as antimicrobial agents and as protection against herbivores, UV radiation and water loss. As such, they are potentially important in the preservation of desert species.

The cytosolic activation of $[3 \mathrm{H}] \mathrm{AFB}_{1}$ was correlated with 5lipoxygenase (LOX) activity and was inhibited by the LOX inhibitor NDGA, which indicates that LOXs are largely responsible for the observed cytosolic activation of $\mathrm{AFB}_{1}$ [10]. Indomethacin produced a $63-100 \%$ decrease in $[3 \mathrm{H}] \mathrm{AFB}_{1}$-DNA binding in macrophages from five of seven patients, while the antioxidant NDGA from Larrea tridentata [77] inhibited [ $3 \mathrm{H}$ ] $\mathrm{AFB}_{1}$-DNA adduct formation by 19,40 and $56 \%$ in macrophages from three patients. Cytochrome $\mathrm{P} 450$ has a minor role in the bioactivation of $\mathrm{AFB}_{1}$ in the human lung [10].

NDGA inhibits the growth of several human cancer types and is useful in cancer therapy including that for breast, prostate, lung, esophageal and skin cancers. These encouraging results suggest a possible chemotherapeutic role for NDGA [73,78-80].

The exact mechanisms by which NDGA exerts its anti-tumorigenic and anti-proliferative effects are still unknown. LOX NDGA suppresses tumor growth via the inhibition of metabolic enzymes as well as receptor tyrosine kinase-phosphorylation, which is overactive in certain cancer cells [81].

\section{Toxicity}

Creosote bush Larrea tridentata J.M. Coult. and its primary metabolite NDGA have been useful in traditional medicine, industry and research, but neither creosote bush nor NDGA has been tested at the clinical level [73]. The toxicity of creosote bush was demonstrated, although the reported toxic doses in humans and experimental animals always exceeded the traditional use of the plant. Creosote bush extracts with NDGA that are used in healing practices are applied as either a topical paste or are consumed as a tea prepared by boiling the extracts in water. This extraction process may transform the compound into a weaker, stronger or even a toxic derivate [82]. Creosote bush was utilized commercially in the United States as a preservative for fats and butter, but it was removed from the FDA's list of safe agents because it induced cystic nephropathy in the rat. However, Larrea-containing products have remained on the dietary-supplement market. Although the consumption of low doses of such products appears to be harmless, high doses have been associated with dermatitis, nephrotoxicity (including renal cell carcinoma), biliary toxicity, and hepatotoxicity (including fulminant liver failure) in humans [83-85]. An interesting finding is that a structural modification of NDGA changed its toxicity in vivo, and at the beginning, the LD50 of NDGA was $75 \mathrm{mg}$ $\mathrm{kg}^{-1}$, whereas its derivative M4N was well-tolerated at $1000 \mathrm{mg} / \mathrm{kg}$ (both given by intraperitoneal injection) [86]. Moreover, other tetra-O- 
Citation: Carvajal-Moreno M, García-Hernández EA, González-Villaseñor MDC, González-Mendoza AE, Rojas-Marín VA (2018) Aflatoxins, Carcinogens in Food, as Etiological Factors in Human Malignant Neoplasias of the Lung. J Cancer Sci Ther 10: 294-301. doi: 10.4172/1948-5956.1000559

substituted NDGA analogs also showed decreased toxicity in vitro, and therefore, the utility of this compound as a medicine is hopeful [87].

\section{Conclusion}

This article summarizes the known etiology of malignant lung neoplasia with respect to $\mathrm{AFB}_{1}$ and $\mathrm{AFG}_{1}$ as human carcinogens, the molecular mechanisms, mutations in the $K$-ras and $H$-ras oncogenes, point mutations and mutations in the p53 tumor suppressor gene and metabolic pathways. This article also discusses a possible biocontrol using Larrea tridentata, which is known as creosote bush, and its toxicological aspects.

\section{Acknowledgments}

The authors express their gratitude to the Postgraduates in Biological Sciences and in Biomedical Sciences of the National Autonomous University of Mexico [Posgrado en Ciencias Biológicas and Posgrado en Ciencias Biomédicas, Universidad Nacional Autónoma de México].

The authors also thank the Instituto de Biología, Universidad Nacional Autónoma de México (IBUNAM) and IBUNAM's personnel: Noemí Chávez from the Secretaría Técnica, Joel Villavicencio, Jorge López, Alfredo Wong, Celina Bernal, Diana Martínez and Julio César Montero. Additionally, we thank Georgina Ortega Leite and Gerardo Arévalo for library information.

\section{References}

1. Bray F, Ren JS, Masuyer E, Ferlay J (2013) Global estimates of cancer prevalence for 27 sites in the adult population in 2008. Int J Cancer 132: 1133-1145.

2. Ferlay J, Soerjomataram I, Ervik M, Dikshit R, Eser S, et al. (2013) GLOBOCAN 2012 v1.0, Cancer incidence and mortality worldwide: IARC cancer base No. 11 [Internet]. Lyon, France: International Agency for Research on Cancer 2: 1.

3. Dvorakova I, Stora C, Ayraud N (1981) Evidence for aflatoxin B1 in two cases of lung cancer in man. J Cancer Res Clin Oncol 100: 221-224.

4. Wogan GN (1991) Aflatoxins as risk factors for primary hepatocellular carcinoma in humans. Pennington Center Nutrition Series 1: 3-17.

5. Harrison JC, Carvajal M, Garner RC (1993) Does aflatoxin exposure in the United Kingdom constitute a cancer risk?. Environ Health Perspect 99: 99-105.

6. Carvajal-Moreno M (2017) Do Gastroenterologists consider Aflatoxins as origin of digestive system disease?. J Pharmacovigil 5: 242.

7. Choi MJ, Lee JW, Lee BM (1996) Comparative assessment of DNA adduct formation, Salmonella mutagenicity, and chromosome aberration assays as short-term tests for DNA damage. J Toxicol Environ Health 49: 271-284.

8. Carvajal M, Berumen J, Guardado-Estrada M (2012) The presence of $\mathrm{AFB}_{1}$-FAPY adduct and human papilloma virus in cervical smears from cancer patients in Mexico. Food Addit Contam 29: 258-268.

9. Travis WD, Brambilla E, Nicholson AG, Yatabe Y, Austin JHM, et al. (2015) Classification of lung tumors impact of genetic, clinical and radiologic advances since the 2004. State of the Art: Concise review, The International Association for the Study of Lung Cancer, WHO. J Thoracic Oncology 10: 1243-1260.

10. Donnelly PJ, Stewart RK, Ali SL, Conlan AA, Reid KR, et al. (1996) Biotransformation of aflatoxin B1 in human lung. Carcinogenesis 17: 2487-2494.

11. Smith GB, Harper PA, Wong JMY, Lam MSM, Reid KR, et al. (2001) Human lung microsomal cytochrome P4501A1 (CYP1A1) activities: Impact of smoking status and $C Y P 1 A 1$, aryl hydrocarbon receptor and glutathione S-transferase M1 genetic polymorphisms. Cancer Epidemiol Biomarkers Prev 10: 839-853.

12. Massey TE, Smith GBJ, Tam AS (2000) Mechanisms of aflatoxin B1 lung tumorigenesis. Exp Lung Res 26: 673-683.

13. Payne GA, Brown MP (1998) Genetics and physiology of aflatoxin biosynthesis. Annu Rev Phytopathol 36: 329-362.

14. Inan F, Pala M, Doymaz I (2007) Use of ozone in detoxification of aflatoxin $B_{1}$ in red pepper. J Stored Prod Res 43: 425-429.

15. Hussein HS, Brasel JM (2001) Toxicity, metabolism, and impact of mycotoxins on humans and animals. Toxicology 167: 101-134.

16. Soriano Del Castillo JM (2007) Micotoxinas en Alimentos. Ed Díaz de Santos, Spain.

17. Pereira VL, Fernandes JO, Cunha SC (2014) Mycotoxins in cereals and related foodstuffs: A review on occurrence and recent methods of analysis. Trends Food Sci Technol 36: 96-136.

18. Pitt JI, Miller JD (2016) A concise history of mycotoxin research. J Agric Food Chem 65: 7021-7033.

19. Krishnamachari K, Bhat RV, Nagarajan V, Tilac T (1975) Investigations into an outbreak of hepatitis in Western India. Indian J Med Res 63: 1036-1048.

20. Vega-Rojas LJ, Carvajal-Moreno M, Rojas-Molina I, Rojo-Callejas F, Ruiz-Velasco S, et al. (2016) The effect of maize germ on the presence of aflatoxins in corn flours treated with a thermo-alkaline process. J Microb Biochem Technol 8: 408-414.

21. Suárez-Bonnet E, Carvajal $\mathrm{M}$, Méndez-Ramírez I, Castillo-Urueta $\mathrm{P}$, Cortés-Eslava J, et al. (2013). Aflatoxin (B1, B2, G1 and G2) contamination in rice of Mexico and Spain, from local sources or imported. J Food Sci 78: 1822-1829.

22. Alvarado-Hernández JR, Carvajal-Moreno M, Rojo-Callejas F, RuizVelasco S (2016) Aflatoxins in natural peanut (Arachis hypogaea L.) of Mexico City: Validation of the immunoaffinity column extraction and HPLC quantification method. J Plant Biochem Physiol 4: 168-178.

23. Gavilán-Ruiz JM, Carvajal-Moreno M, Rojo-Callejas F, Ruiz-Velasco $\mathrm{S}$ (2015) Aflatoxins in pistachios consumed in Mexico. Natural Prod Chem Res 3: 174-179.

24. Picot A, Ortega-Beltran A, Puckett RD, Siegel JP, Michailides TJ (2017) Period of susceptibility of almonds to aflatoxin contamination during development in the orchard. Eur J Plant Pathol 148: 521-531.

25. Adaya-González J, Carvajal-Moreno M, Rojo-Callejas F, Ruiz-Velasco S (2015) Aflatoxins in walnut (Juglans regia L.), pecan (Carya illinoinensis (Wangenh.) K. Koch) and cashew (Anacardium occidentale L.) nuts of Mexico. Pharm Anal Acta 6: 338-348.

26. Rosas-Contreras C, Carvajal-Moreno M, Rojo-Callejas F, Ruiz-Velasco S (2016) Identification and HPLC quantification of aflatoxins in dried hot peppers (Capsicum annum L.), in Mexico and other countries. J Drug MetabToxicol 6: 198-208.

27. Garduño-García JI, Carvajal-Moreno M, Rojo-Callejas F, Ruiz-Velasco S (2017) Detection of Aflatoxins, mutagens and carcinogens, in black, white and green peppers (Piper nigrum L.). J Microbial Biochem Technol 9: 95-104.

28. Bennett JW, Klich M (2003) Mycotoxins. Clin Microbiol Rev 16: 497-516.

29. Carvajal M, Bolaños A, Rojo F, Méndez I (2003) Aflatoxin M1 in pasteurized and ultra-pasteurized milk with different fat content in Mexico. J Food Protect 66: 1885-1892.

30. Barbiroli A, Bonomi F, Benedetti S, Mannino S, Monti L, et al. (2007) Binding of aflatoxin M1 to different protein fractions in ovine and caprine milk. J Dairy Sci 90: 532-540.

31. Wyllie TD, Morehouse LG (1978) Mycotoxin fungi, mycotoxins, mycotoxicoses. An Encyclopedic Handboook 3. Mercel Dekker Inc, New York, USA.

32. Jeffrey AM, Williams GM (2005) Risk assessment of DNA-reactive carcinogens in food. Toxicol Appl Pharmacol 207: S628-S635.

33. IARC, International Agency for Research on Cancer (2002) Some traditional herbal medicines, some mycotoxins, naphthalene and styrene. 
Citation: Carvajal-Moreno M, García-Hernández EA, González-Villaseñor MDC, González-Mendoza AE, Rojas-Marín VA (2018) Aflatoxins, Carcinogens in Food, as Etiological Factors in Human Malignant Neoplasias of the Lung. J Cancer Sci Ther 10: 294-301. doi: $10.4172 / 1948-5956.1000559$

Monographs on the Evaluation of Carcinogenic Risks to Humans, 82. Lyon (France): IARC p: 171.

34. Ostry V, Malir F, Toman J, Grosse Y (2017) Mycotoxins as human carcinogens - the IARC Monographs classification. Mycotoxin Res 33: 65-73.

35. Robens JF, Richard JL (1992) Aflatoxins in animal and human health. Rev Environ Contam Toxicol 127: 69-94.

36. Essigmann JM, Croy RG, Bennett RA, Wogan GN (1982) Metabolic activation of aflatoxin B1 patterns of DNA adduct formation, removal, and excretion in relation to carcinogenesis. Drug Metab Rev 13: 581-602.

37. Essigmann JM, Croy RG, Nadzan AM, Busby WF Jr, Reinhold VN, et al (1977) Structural identification of the major DNA adduct formed by Aflatoxin B1 in vitro. Proc Natl Acad Sci USA 74: 1870-1874.

38. Smela ME, Currier SS, Bailey EA, Essigmann J (2001) The chemistry and biology of aflatoxin B1: From mutational spectrometry to carcinogenesis. Carcinogenesis 22: 535-545.

39. Zarba A, Hmieleski R, Hemenway DR, Jakab GJ, Groopman JD (1992) Aflatoxin B1- DNA adduct formation in rat liver following exposure by aerosol inhalation. Carcinogenesis 13: 1031-1033.

40. Biswas G, Raj HG, Allameh A, Saxena M, Srivastava N, et al. (1993) Comparative kinetic studies on aflatoxin B1 binding to pulmonary and hepatic DNA of rat and hamster receiving the carcinogen intratracheally. Teratog Carcinog Mutagen 13: 259-268.

41. Salbe AD, Bjeldanes LF (1989) Effect of diet and route of administration on the DNA binding of aflatoxin B1 in the rat. Carcinogenesis 10: 629-634.

42. Putt DA, Ding X, Coon MJ, Hollenberg PF (1995) Metabolism of aflatoxin $\mathrm{B} 1$ by rabbit and rat nasal mucosa microsomes and purified cytochrome P450, including isoforms $2 \mathrm{~A} 10$ and 2A11. Carcinogenesis 16: 1411-1417.

43. Larsson P, Tjalve H (1995) Extrahepatic bioactivation of Aflatoxin B1 in fetal, infant and adult rats. Chem Biol Interact 94: 1-19.

44. Zhang Z, Liu HY, Huan F, Meghan C, Yang XJ, et al. (2014) Cytochrome P450 2A13 mediates the neoplastic transformation of human bronchial epithelial cells at a low concentration of aflatoxin B1. Int J Cancer 134: 1539-1548.

45. He XY, Tang L, Wang SL, Cai QS, Wang JS, et al. (2006) Efficient activation of aflatoxin B1 by cytochrome P450 2A13, an enzyme predominantly expressed in human respiratory tract. Int J Cancer 118: 2665-2671.

46. Marnett LJ (1990) Prostaglandin synthase-mediated metabolism of carcinogens and a potential role for peroxyl radicals as reactive intermediates. Environ Health Perspect 88: 5-12.

47. Dvorak AM, Schleimer RP, Dvorak HF, Lichtenstein LM, Weller PF (1992) Human lung mast cell and alveolar macrophage cytoplasmic lipid bodies contain arachidonic acid and prostaglandin endoperoxide synthase (cyclooxygenase), the substrate and enzyme necessary for prostaglandin production. Int Arch Allergy Immunol 99: 208-217.

48. Hughes MF, Chamulitrat W, Mason RP, Eling TE (1989) Epoxidation of 7, 8-dihydroxy-7, 8-dihydrobenzo [a] pyrene via a hydroperoxidasedependent mechanism catalyzed by lipoxygenases. Carcinogenesis 10: 2075-2080.

49. Willey JC, Coy E, Brolly C, Utell MJ, Frampton MW, et al. (1996) Xenobiotic metabolism enzyme gene expression in human bronchial and alveolar macrophage cells. Am J Respir Cell Mol Biol 14: 262-271.

50. Anderson MW (1991) Oncogenes, growth factors, and cell signaling in mouse lung tumors: An overview. Exp Lung Res 17: 323-325.

51. Jackson MA, Lea I, Rashid A, Peddada SD, Dunnick JK (2006) Genetic alterations in cancer knowledge system: Analysis of gene mutations in mouse and human liver and lung tumors. Toxicol Sci 90: 400-418.

52. Wang JS, Groopman JD (1999) DNA damage by mycotoxins. Mutat Res 424: $167-181$.

53. Hofseth LJ, Hussain SP, Harris CC (2004) p53: 25 years after its discovery. Trends Pharmacol Sci 25: 177-181.
54. Hsu IC, Metcalf RA, Sun T, Welsh JA, Wang NJ, et al. (1991) Mutational hotspot in the p53 gene in human hepatocellular carcinomas. Nature 350: 427-428.

55. Paget V, Lechevrel M, Ronique A (2012). Benzo[a] pyrene, Aflatoxin B-1 and acetaldehyde mutational patterns in TP53 gene using a functional assay: Relevance to human cancer. Aetiology 7: e30921.

56. McMahon G, Davis EF, Huber LJ, Kim Y, Wogan GN (1990) Characterization of c-Ki-ras and $\mathrm{N}$-ras oncogenes in aflatoxin B1induced rat liver tumors. Proc Natl Acad Sci USA 87: 1104-1108.

57. Habib SL, Said B, Awad AT, Mostafa MH, Shank RC (2006) Novel adenine adducts, N7-guanine- $\mathrm{AFB}_{1}$ adducts, and p53 mutations in patients with schistosomiasis and aflatoxin exposure. Cancer Detect Prev 30: 491-498.

58. Kamdem LK, Meineke I, Gödtel-Armbrust U, Brockmöller J, Wojnowski L (2006) Dominant contribution of P450 3A4 to the hepatic carcinogenic activation of aflatoxin B1. Chem Res Toxicol 19: 577-586.

59. Hussain SP, Schwank J, Staib F, Wang XW, Harris CC (2007) TP53 Mutations and hepatocellular carcinoma: insights into the etiology and pathogenesis of liver cancer. Oncogene 26: 2166-2176.

60. Guindon KA, Foley JF, Maronpot RR, Massey TE (2008) Failure of catalase to protect against aflatoxin B1-induced mouse lung tumorigenicity. Toxicol Appl Pharmacol 227:179-183.

61. Van Vleet TR, Watterson TL, Klein PJ, Coulombe RA (2006) Aflatoxin B-1 alters the expression of p53 in cytochrome P450-expressing human lung cells. Toxicol Sci 89: 399-407.

62. Tam AS, Foley JF, Devereux TR, Maronpot RR, Massey TE (1999) High frequency and heterogeneous distribution of p53 mutations in Aflatoxin B1- induced mouse lung tumors. Cancer Res 59: 3634-3640.

63. Levine AJ, Oren M (2009) The first 30 years of p53: growing ever more complex. Nat Rev Cancer 9: 749-758.

64. Kumar V, Abbas AK, Fausto N, Aster J (2009) Molecular basis of cancer Saunders (Elsevier). Robbins \& Cotran Pathologic Basis of Disease, $8^{\text {th }}$ (eds.) USA.

65. Vassilev LT, Vu BT, Graves B, Carvajal D, Podlaski F et al. (2004) In vivo activation of the p53 pathway by small-molecule antagonists of MDM2. Science 6: 844-848.

66. Lodish H, Berk A, Matsudaira P, Kaiser CA, Krieger M, et al. (2004) Molecular cell biology ( $5^{\text {th }}$ eds.) Nueva York: WH Freeman and CO pp: 66-72.

67. Ito A, Kawaguchi Y, Lai CH, Kovacs JJ, Higashimoto Y, et al. (2002) MDM2-HDAC1-mediated deacetylation of p53 is required for its degradation. EMBO J 21: 6236-6245.

68. Yaffe MB (2013) The scientific drunk and the lamppost: Massive sequencing efforts in cancer discovery and treatment. Sci Signal 6: 13.

69. Mulder JK, Bondy GS, Mehta R, Massey TE (2014) Up-regulation of nucleotide excision repair in mouse lung and liver following chronic exposure to aflatoxin B-1 and its dependence on p53 genotype. Toxicol Appl Pharmacol 275: 96-103.

70. Liu C, Shen H, Yi L, Shao P, Soulika AM, et al. (2015) Oral administration of aflatoxin G1 induces chronic alveolar inflammation associated with lung tumorigenesis. Toxicol Lett 232: 547-556.

71. Georggiett OC, Muiño JC, Montrull H, Brizuela N, Avalos S, et al. (2000) Relationship between lung cancer and aflatoxin B1. Rev Fac Cien Med Univ Nac Cordoba 57: 95-107.

72. Pribitkin ED, Boger G (2001) Herbal therapy: What every facial plastic surgeon must know. Arch Facial Plast Surg 3: 127-132.

73. Arteaga S, Andrade-Cetto A, Cardenas R (2005) Larrea tridentata (Creosote bush), an abundant plant of Mexican and US-American deserts and its metabolite nordihydroguaiaretic acid. J Ethnopharmacol 98: 231-239.

74. Lia VV, Confalonieri VA, Comas CI, Hunziker JH (2001) Molecular phylogeny of Larrea and its allies (Zygophyllaceae): Reticulate evolution and the probable time of creosote bush arrival to North America. Mol Phylogenet Evol 21: 309-320. 
Citation: Carvajal-Moreno M, García-Hernández EA, González-Villaseñor MDC, González-Mendoza AE, Rojas-Marín VA (2018) Aflatoxins, Carcinogens in Food, as Etiological Factors in Human Malignant Neoplasias of the Lung. J Cancer Sci Ther 10: 294-301. doi: 10.4172/1948-5956.1000559

75. Lara-Ochoa F, Marquez C (1996) Medicinal plants from Mexico: Composition, uses and biological activity. Dirección General de Publicaciones. UNAM. Mexico.

76. Konno C, Lu ZZ, Xue HZ, Erdelmeier CA, Meksuriyen D, et al. (1990) Furanoid lignans from Larrea tridentata. J Nat Prod 53: 396-406.

77. Lü JM, Nurko J, Weakley SM, Jiang J, Kougias P, et al. (2010) Molecular mechanisms and clinical applications of nordihydroguaiaretic acid (NDGA) and its derivatives: An update. Med Sci Monit 16: RA93-R100.

78. Ansar S, Iqbal M, Athar M (1999) Nordihydroguaiaretic acid is a potent inhibitor of ferric-nitrilotriacetate-mediated hepatic and renal toxicity, and renal tumour promotion, in mice. Carcinogenesis 20: 599-606.

79. Huang JK, Chen WC, Huang CJ, Hsu SS, Chen JS, et al. (2004) Nordihydroguaiaretic acid-induced $\mathrm{Ca}^{2+}$ handling and cytotoxicity in human prostate cancer cells. Life Sci 75: 2341-2351.

80. Moody TW, Leyton J, Martinez A, Hong S, Malkinson A, et al. (1998) Lipoxygenase inhibitors prevent lung carcinogenesis and inhibit nonsmall cell lung cancer growth. Exp Lung Res 24: 617-628.

81. Blecha JE, Anderson MO, Chow JM, Guevarra CC, Pender C, et al. (2007) Inhibition of IGF-1R and lipoxygenase by nordihydroguaiaretic acid (NDGA) analogs. Bioorg Med Chem Lett 17: 4026-4029.

82. Billinsky JL, Krol ES (2008) Nordihydroguaiaretic acid autoxidation produces a schisandrin-like dibenzocyclooctadiene lignan. J Nat Prod 71: $1612-1615$.
83. Lambert JD, Zhao D, Meyers RO, Kuester RK, Timmermann BN, et al. (2002) Nordihydroguaiaretic acid: Hepatotoxicity and detoxification in the mouse. Toxicon 40: 1701-1708.

84. Obermeyer WR, Musser SM, Betz JM, Casey RE, Pohland AE, et al. (1995) Chemical studies of phytoestrogens and related compounds in dietary supplements: Flax and chaparral. Proc Soc Exp Biol Med 208: 6-12.

85. Alderman S, Kailas S, Goldfarb S, Singaram C, Malone DG (1994) Cholestatic hepatitis after ingestion of chaparral leaf: Confirmation by endoscopic retrograde cholangiopancreatography and liver biopsy. J Clin Gastroenterol 19: 242-247.

86. Chang CC, Heller JD, Kuo J, Huang RC (2004) Tetra-O-methyl nordihydroguaiaretic acid induces growth arrest and cellular apoptosis by inhibiting Cdc2 and survivin expression. Proc Natl Acad Sci USA 101: 13239-13244.

87. Meyers RO, Lambert JD, Hajicek N, Pourpak A, Kalaitzis JA, et al. (2009) Synthesis, characterization, and anti-melanoma activity of tetra-Osubstituted analogs of nordihydroguaiaretic acid. Bioorg Med Chem Lett 19: 4752-4755. 